\title{
Age-Friendly Primary Healthcare Development and Achievements in Taiwan
}

\author{
Wen-Chun Chen
}

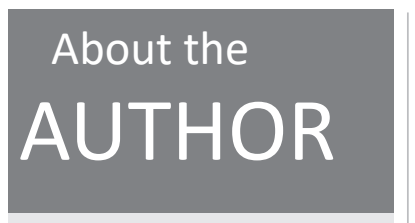

St. Martin De Porres Hospital, Chiayi, Taiwan

Contact:

Wen-Chun Chen shermie@stm.org.tw

\section{Introduction}

In 2018, Taiwan's elderly population reached $14.56 \%$, turning Taiwan into an aged society (1). In response to the increasing aging population, starting in 2009, the Health Promotion Administration began promoting the accreditation ofage-friendlyhealthcare institutions nationwide, and further expanded this in 2012 to public health centers/ health service centers, local clinics, long-term care institutions, etc.

\section{National response led by the government}

The Taiwanese medical institutions have greatly supported the efforts and initiative from the Taiwanese Administration to promote accreditation of age-friendly healthcare institutions. Of these institutions, public health centers/ health service centers are distributed throughout Taiwan. This highlights the importance of the age-friendly issue at primary health care, in particular in rural/remote townships with lack of medical resources and massive outward migrations of their young adult populations. Therefore, to create a localized age-friendly environment and with the government's policies in lead, the accreditation coverage rate is as high as $89.1 \%$ (2).

\section{Spare no efforts to raise the level of professional knowledge}

During the process of promoting agefriendlyhealthcareinstitutions, theHealth
Promotion Administration continuously provided public health centers/health service centers with opportunities to raise the level of professional knowledge through educative training sessions in the respective regions of north, central, south, and east Taiwan. For example, in 2018, there were a total of six educative training sessions held in Taiwan, which included a total of 822 participants. During the evaluation of the difference in knowledge before and after these training sessions, all participants showed significant increase in the level of understanding for contents of the five accreditation domains and the core classes such as geriatric syndrome, comprehensive geriatric assessment, multiple comorbidities and health literacy on age-friendly care (Table 1 and Table 2) (3). In addition to demonstrating that the topics and contents of these educative training sessions were well planned, it also strengthened the care knowledge of primary care professionals on agefriendly healthcare and greatly increased the ability of the elderly and their families to monitor their own health and care.

\section{Conclusion}

Promoting the accreditation of agefriendly healthcare institutions can facilitate changing healthcare institutions at the primary care level. Filial piety and respect for the elderly are elements assimilated within the accreditation provisions, and this promotes the integration of even more meticulous friendly care for the elderly along with strengthening of age-friendly healthcare 


\section{Research and Best Pratice}

Table 1. Analysis on the differences in knowledge before and after the certification seminar and educative training sessions (Taitung event) $n=160$

\begin{tabular}{|c|c|c|c|c|c|}
\hline Question & Pre-test & Post-test & SD & 95\% C.I. & $p$-value ${ }^{a}$ \\
\hline $\begin{array}{l}\text { 1. What is your level of understanding on the } \\
\text { "certification work process of elderly friendly } \\
\text { healthcare institutions"? }\end{array}$ & 2.77 & 4.02 & 0.90 & 1.02 to 1.47 & $<0.001$ \\
\hline $\begin{array}{l}\text { 2. What is your level of understanding on basis } \\
\text { standard } 4 \text { (health promotion)? }\end{array}$ & 2.91 & 3.98 & 0.92 & 0.85 to 1.30 & $<0.001$ \\
\hline $\begin{array}{l}\text { 3. What is your level of understanding on basis } \\
\text { standard } 5 \text { (community service and referral)? }\end{array}$ & 2.68 & 4.00 & 0.85 & 1.11 to 1.54 & $<0.001$ \\
\hline $\begin{array}{l}\text { 4. What is your level of understanding on basis } \\
\text { standard } 3 \text { (friendly environment)? }\end{array}$ & 2.83 & 4.02 & 1.07 & 0.92 to 1.45 & $<0.001$ \\
\hline $\begin{array}{l}\text { 5. Do you understand "community environments" } \\
\text { that harm elders? }\end{array}$ & 2.82 & 4.02 & 0.96 & 0.98 to 1.42 & $<0.001$ \\
\hline $\begin{array}{l}\text { 6. What is your level of understanding on basis } \\
\text { standard } 1 \text { (policy management)? }\end{array}$ & 2.72 & 3.97 & 0.97 & 1.02 to 1.47 & $<0.001$ \\
\hline $\begin{array}{l}\text { 7. What is your level of understanding on basis } \\
\text { standard } 2 \text { (information intervention and commu- } \\
\text { nication)? }\end{array}$ & 2.60 & 4.02 & 0.83 & 1.22 to 1.61 & $<0.001$ \\
\hline $\begin{array}{l}{ }^{a} \text { t-test between pre-test and post-test } \\
\mathrm{SD}=\text { standard deviation } \\
\text { C.I.=Confidence Interval }\end{array}$ & \multicolumn{3}{|c|}{$\begin{array}{l}\text { p-value is based on the t-test } \\
\text { Significant is at the } 5 \% \text { level }\end{array}$} & & \\
\hline
\end{tabular}

Table 2. Analysis on the differences in knowledge before and after core training classes (Taitung event) n=160

\begin{tabular}{|c|c|c|c|c|c|}
\hline Question & Pre-test & Post-test & SD & 95\% C.I. & p-value \\
\hline $\begin{array}{l}\text { 1. Do you understand "geriatric syndrome and } \\
\text { comprehensive geriatric assessment"? }\end{array}$ & 2.70 & 4.01 & 0.91 & 1.11 to 1.51 & $<0.001$ \\
\hline $\begin{array}{l}\text { 2. Do you understand the "multiple comorbidities } \\
\text { and complex requirements" of the elderly? }\end{array}$ & 2.76 & 3.97 & 0.93 & 1.00 to 1.43 & $<0.001$ \\
\hline $\begin{array}{l}\text { 3. Do you understand the meaning of "health } \\
\text { literacy"? }\end{array}$ & 2.89 & 3.97 & 0.97 & 0.86 to 1.31 & $<0.001$ \\
\hline $\begin{array}{l}\text { a t-test between pre-test and post-test } \\
\mathrm{SD}=\text { Standard Deviation }\end{array}$ & & $\begin{array}{l}\text { based on } \\
t \text { is at the }\end{array}$ & & & \\
\hline
\end{tabular}

strategies. With health promotion as a basis, the establishment of long-term caring relationships allows the elderly to age and reside locally in healthier places and is a strategy worthwhile for other nations to follow.

\section{Reference}

(1) National Development Council, Proportion of population aged $65+(\%)$ Population Projections for the R. O. C. (Taiwan); 2018 Aug.

https://pop-proj.ndc.gov.tw/chart.aspx?c=10\&uid=66\&pid=60

(2) Health Promotion Administration, Ministry of Health and Welfare, The distribution of 609 age-friendly health care certified institutions (performance in 2018); 2019 Mar.

https://www.hpa.gov.tw/Pages/Detail.aspx?nodeid=539\&pid=10455

(3) Chen, W. (Ditmanson Medical Foundation Chia-Yi Christian Hospital, Chia-Yi City). 2018 Project of the promotion of age-friendly health care certified institutions. No. D1061224. 